Western University

Scholarship@Western

Chemistry Publications

Chemistry Department

9-18-2007

\title{
Reduction of Esters to Ethers Utilizing the Powerful Lewis Acid BF2OTf.OEt2
}

Brian Pagenkopf

University of Western Ontario, bpagenko@uwo.ca

Nicholas A. Morra

Follow this and additional works at: https://ir.lib.uwo.ca/chempub

Part of the Chemistry Commons

Citation of this paper:

Pagenkopf, Brian and Morra, Nicholas A., "Reduction of Esters to Ethers Utilizing the Powerful Lewis Acid BF2OTf.OEt2" (2007). Chemistry Publications. 57.

https://ir.lib.uwo.ca/chempub/57 


\title{
Reduction of Esters to Ethers Utilizing the Powerful Lewis Acid $\mathrm{BF}_{2} \mathrm{OTf} \bullet \mathrm{OEt}_{2}$
}

\author{
Nicholas A. Morra, Brian L. Pagenkopf* \\ Department of Chemistry, The University of Western Ontario, 1151 Richmond Street, London, ON, N6A 5B7, Canada \\ Fax: +1 (519) 661-3022 \\ E-mail: bpagenko@uwo.ca \\ Received: The date will be inserted once the manuscript is accepted.
}

\begin{abstract}
The direct reduction of esters to their corresponding ethers has been achieved using the Lewis acid $\mathrm{BF}_{2} \mathrm{OTf} \cdot \mathrm{OEt}_{2}$ generated via anionic redistribution between TMSOTf and $\mathrm{BF}_{3} \bullet \mathrm{OEt}_{2}$ with triethyl silane acting as the reducing agent. Isolated yields of up to $71 \%$ have been obtained with the corresponding alcohol as the only side product.
\end{abstract}

Key words: boron, esters, ethers, Lewis acid, reductions

Lewis acids have played a fundamental role in the advancement of organic chemistry by improving reaction yields, increasing selectivity or mediating otherwise difficult reactions. ${ }^{1}$ Carbonyl Lewis acid complexes in particular have generated a great deal of attention and have been thoroughly studied in the carbonyl ene reaction, ${ }^{2}$ addition of allyl silanes or stannanes to aldehydes and conjugated enones, ${ }^{3}$ as well as Diels-Alder ${ }^{4}$ and aldol reactions. ${ }^{5}$ In these examples, coordination of the Lewis acid to the carbonyl oxygen results in increased reactivity at the carbonyl carbon.

The reduction of esters to alcohols is a commonplace synthetic transformation that can be accomplished with a variety of hydride sources (Scheme 1A), but the direct reduction of esters to ethers is less well known (Scheme 1B). Such ester to ether reductions have been observed in the presence of strongly electron withdrawing Lewis acids. ${ }^{6}$ For example, in work on the reductive cleavage of polysaccharides Gray noted the inadvertent reduction of a $\mathrm{C} 2$ propionate ester side chain to its corresponding propyl ether. ${ }^{7}$ The system employed consisted of a 5:1 mixture of TMSOMs: $\mathrm{BF}_{3} \cdot \mathrm{OEt}_{2}$ in $\mathrm{CH}_{2} \mathrm{Cl}_{2}$ with $\mathrm{Et}_{3} \mathrm{SiH}$ serving as the hydride source. These results clearly showed that with the right Lewis acid it is possible to coax the collapse of the tetrahedral intermediate through a different reaction manifold thereby leading directly to ether formation. A general method for the direct formation of ethers from esters would provide a highly desirable alternative to the classical Williamson ether synthesis. ${ }^{8}$

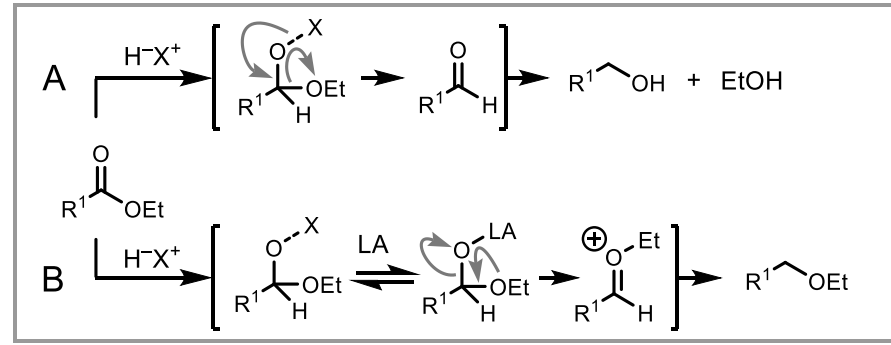

Scheme 1 The well-known reduction of esters to alcohols (A), and an alternative pathway to ether formation (B)
We sought to build on this early observation by confirming the nature of the Lewis acid responsible for ether formation, and by exploring the potential generality of this reduction. In the initial literature report it was proposed that the mixture of TMSOMs and $\mathrm{BF}_{3} \bullet \mathrm{OEt}_{2}$ underwent anionic redistribution to form the active species of either $\mathrm{BF}_{2} \mathrm{OMs} \bullet \mathrm{OEt}_{2}$ or $\mathrm{BF}(\mathrm{OMs})_{2} \cdot \mathrm{OEt}_{2} .{ }^{9}$ In order for us to further clarify the nature of the anionic redistribution, no-D ${ }^{11} \mathrm{~B}$ and ${ }^{19} \mathrm{~F}$ NMR were taken of solutions of TMSOMs and $\mathrm{BF}_{3} \bullet^{\circ} \mathrm{OEt}_{2}$ in $1: 1,5: 1$, and $10: 1$ ratios. ${ }^{10}$ It was found that the parent Lewis acids underwent a single anionic redistribution only, to produce $\mathrm{BF}_{2} \mathrm{OMs} \cdot \mathrm{OEt}_{2}$ and TMSF. The reaction was very rapid at room temperature, and had reached equilibrium $\left(\mathrm{K}_{e q}=1.45\right)$ within a few minutes (Scheme 2A).

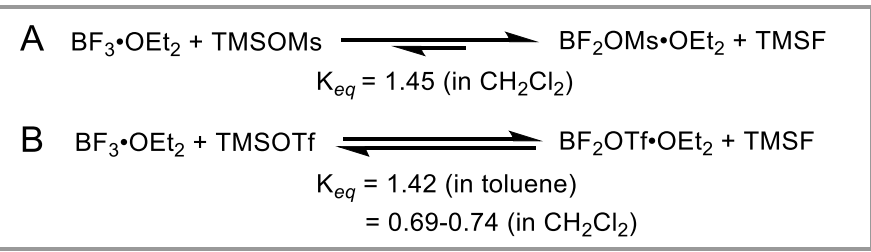

Scheme 2 In situ generation of $\mathrm{BF}_{2} \mathrm{OMs} \cdot \mathrm{OEt}_{2}$ and $\mathrm{BF}_{2} \mathrm{OTf} \bullet \mathrm{OEt}_{2}$

Initial reductions of model ester hydrocinnamyl acetate using the original system ${ }^{7}$ of $\mathrm{TMSOMs}$ and $\mathrm{BF}_{3} \cdot \mathrm{OEt}_{2}$ with $\mathrm{Et}_{3} \mathrm{SiH}$ as a reducing agent gave a modest $25 \%$ isolated yield of hydrocinnamyl ethyl ether (Table 1, entry 1). The normal reduction product, hydrocinnamyl alcohol, predominated at $66 \%$ yield along with $7 \%$ of the triethyl silyl ether. No reduction occurs in the absence of either TMSOMs or $\mathrm{BF}_{3} \cdot \mathrm{OEt}_{2}$ which further supports the idea that $\mathrm{BF}_{2} \mathrm{OMs}^{\bullet} \mathrm{OEt}_{2}$ was responsible for moderating the ester to ether reduction. We speculated that enhancing the Lewis acidity of the active species might lead to more ether formation, and therefore the mesylate was replaced with a triflate. The $\mathrm{BF}_{2} \mathrm{OTf} \bullet \mathrm{OEt}_{2}$ was prepared in a manner analogous to that of $\mathrm{BF}_{2} \mathrm{OMs}^{\bullet} \mathrm{OEt}_{2}$, that is, simply by mixing TMSOTf and $\mathrm{BF}_{3} \bullet \mathrm{OEt}_{2}$ in a 5:1 ratio, and as with $\mathrm{BF}_{2} \mathrm{OMs} \bullet \mathrm{OEt}_{2}$, the redistribution was complete within minutes. ${ }^{19} \mathrm{~F}$ NMR studies of the reaction between TMSOTf and $\mathrm{BF}_{3} \cdot \mathrm{OEt}_{2}$ in toluene gave an equilibrium constant of 1.42 , compared to $0.69-0.74$ in $\mathrm{CH}_{2} \mathrm{Cl}_{2}$ (Scheme 2B). ${ }^{11}$ 
Table 1 Comparison of reductions with $\mathrm{BF}_{2} \mathrm{OMs} \bullet \mathrm{OEt}_{2}$ or $\mathrm{BF}_{2} \mathrm{OTf} \bullet \mathrm{OEt}_{2}$

\begin{tabular}{|c|c|c|c|c|c|}
\hline Entry & TMS-sulfonate & Solvent & Ether $(\%)^{\mathrm{a}}$ & Alcohol $(\%)^{\mathrm{a}}$ & Silyl Ether $(\%)^{\mathrm{a}}$ \\
\hline 1 & TMSOMs & $\mathrm{CH}_{2} \mathrm{Cl}_{2}$ & 25 & 66 & 7 \\
\hline 2 & TMSOTf & $\mathrm{CH}_{2} \mathrm{Cl}_{2}$ & 45 & 46 & 7 \\
\hline 3 & TMSOTf & Toluene & 51 & 40 & 7 \\
\hline
\end{tabular}

${ }^{\mathrm{a}}$ Isolated Yields

The use of $\mathrm{BF}_{2} \mathrm{OTf} \cdot \mathrm{OEt}_{2}$ in the reduction resulted in an improvement in ether formation to $45 \%$ (Table 1 , entry 2), along with the alcohol (46\%) and silyl ether (7\%). A screening of various solvents found reactions in toluene gave a higher yield (Table 1, entry 3 ). Recently, Aggarwal and co workers described the in situ formation of $\mathrm{BF}_{2} \mathrm{OTf} \cdot \mathrm{OEt}_{2}$ and its use in MoritaBaylis-Hillman-type reactions. ${ }^{11,12}$

In an attempt to reduce the amount of TMSOTf used to generate the active Lewis acid, a 1:1 mixture of the parent Lewis acids in toluene was placed under reduced pressure $(40 \mathrm{mmHg}, \mathrm{rt})$ for two hours to remove the volatile TMSF and push the equilibrium further towards $\mathrm{BF}_{2} \mathrm{OTf} \bullet \mathrm{OEt}_{2}$ formation (Scheme $3 \mathrm{~A}$ ). A persistent white suspension immediately began to form upon evacuation and NMR analysis of the mixture suggested that approximately $15 \%$ of the $\mathrm{BF}_{2} \mathrm{OTf} \bullet \mathrm{OEt}_{2}$ underwent further anionic redistribution to produce $\mathrm{BF}_{3} \bullet \mathrm{OEt}_{2}, \quad \mathrm{BF}(\mathrm{OTf})_{2} \bullet \mathrm{OEt}_{2}$, and $\mathrm{B}(\mathrm{OTf})_{3} \cdot \mathrm{OEt}_{2}($ Scheme $3 \mathrm{~B}){ }^{13}$

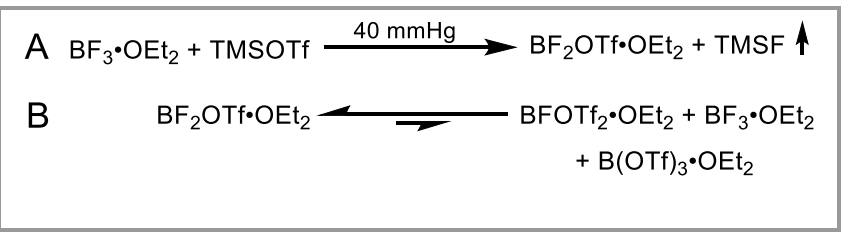

Scheme 3 Competing reactions in the formation of $\mathrm{BF}_{2} \mathrm{OTf} \cdot \mathrm{OEt}_{2}$
Use of the mixture containing di and tri triflate species was found to be disadvantageous in reduction reactions, and, in this regard, it was found that their production could be decreased to undetectable levels by adding an excess of $\mathrm{BF}_{3} \cdot \mathrm{OEt}_{2}$ to the system prior to placing it under reduced pressure. In doing so, we successfully generated $\mathrm{BF}_{2} \mathrm{OTf} \cdot \mathrm{OEt}_{2}$ in situ free of TMSF, TMSOTf, BF(OTf $)_{2} \bullet \mathrm{OEt}_{2}$ and $\mathrm{B}(\mathrm{OTf})_{3} \bullet \mathrm{OEt}_{2}$.

Additional reductions of aliphatic esters were performed with the new TMSF-free Lewis acid system, and not only was a marked improvement in the yields observed, but the undesired silyl ether was no longer produced $^{14}$ (Table 2). This reaction was found to be successful with esters of varying steric hindrance, including hydrocinnamyl acetate (entry 1, 62\%), isobutrate (entry 2, 58\%), pivalate (entry 3,57\%) and formate (entry 4, 62\%). Other esters include methyl hydrocinnamate (entry 5, 70\%) and hydrocinnamyl hydrocinnamate (entry $6,71 \%$ ). Complete conversion required up to 5 days at room temperature for the bulky pivalate ester (entry 3 ), and attempts to shorten reaction times by heating above $25{ }^{\circ} \mathrm{C}$ resulted in significantly lower yields.

Table 2 Reductions of esters with varying steric hindrance

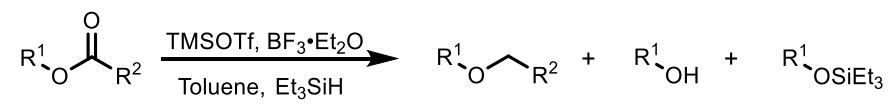

\begin{tabular}{|c|c|c|c|c|c|c|c|}
\hline Entry & $\mathrm{R}^{1}$ & $\mathrm{R}^{2}$ & Time (h) & Conditions $^{\mathrm{a}}$ & Ether $(\%)^{\mathrm{b}}$ & Alcohol $(\%)^{\mathrm{b}}$ & Silyl Ether (\%) \\
\hline \multirow[t]{2}{*}{1} & $\mathrm{Ph}\left(\mathrm{CH}_{2}\right)_{3^{-}}$ & $\mathrm{Me}$ & 28 & $\mathrm{~A}$ & 50 & 41 & 8 \\
\hline & & & & $\mathrm{B}$ & 62 & 36 & 0 \\
\hline \multirow[t]{2}{*}{2} & $\mathrm{Ph}\left(\mathrm{CH}_{2}\right)_{3-}$ & $\mathrm{iPr}$ & 72 & A & 47 & 44 & 6 \\
\hline & & & & B & 58 & 40 & 0 \\
\hline \multirow[t]{2}{*}{3} & $\mathrm{Ph}\left(\mathrm{CH}_{2}\right)_{3^{-}}$ & $\mathrm{tBu}$ & 120 & A & 47 & 47 & 4 \\
\hline & & & & B & 57 & 42 & 0 \\
\hline \multirow[t]{2}{*}{4} & $\mathrm{Ph}\left(\mathrm{CH}_{2}\right)_{3-}$ & $\mathrm{H}$ & 24 & A & 46 & 48 & 3 \\
\hline & & & & B & 62 & 36 & 0 \\
\hline
\end{tabular}




\begin{tabular}{|c|c|c|c|c|c|c|c|}
\hline \multirow[t]{2}{*}{5} & $\mathrm{Me}$ & $\mathrm{Ph}\left(\mathrm{CH}_{2}\right)_{2^{-}}$ & 48 & A & 52 & - & - \\
\hline & & & & B & 70 & - & - \\
\hline \multirow[t]{2}{*}{6} & $\mathrm{Ph}\left(\mathrm{CH}_{2}\right)_{3-}$ & $\mathrm{Ph}\left(\mathrm{CH}_{2}\right)_{2-}$ & 72 & A & 67 & 20 & 9 \\
\hline & & & & B & 71 & 26 & 0 \\
\hline
\end{tabular}

\footnotetext{
${ }^{\mathrm{a}}$ Reaction conditions: $\mathrm{A}=6$ eq TMSOTf, 1.2 eq BF${ }_{3} \cdot \mathrm{OEt}_{2} ; \mathrm{B}=1.2$ eq TMSOTf, $1.8 \mathrm{eq} \mathrm{BF}{ }^{\bullet} \mathrm{OEt}_{2}$, reduced pressure $(40 \mathrm{mmHg}, 2 \mathrm{hours})$

${ }^{\mathrm{b}}$ Isolated Yields
}

Several other reducing agents were examined including triphenylsilane, catecholborane, tributyl tin hydride, triacetoxy borohydride and poly(methylhydrosiloxane)..$^{15}$ Unfortunately, none of these hydride sources resulted in any reduction of the starting esters in the presence of TMSF-free $\mathrm{BF}_{2} \mathrm{OTf} \bullet \mathrm{OEt}_{2}$. Reactions in $\mathrm{CH}_{2} \mathrm{Cl}_{2}$ or toluene of aromatic esters, including electron rich and electron deficient examples, lead to complex reaction mixtures presumably due to Friedel-Crafts type processes.

In summary, the direct reduction of esters to ethers has been achieved using triethyl silane in the presence of $\mathrm{BF}_{2} \mathrm{OTf} \cdot \mathrm{OEt}_{2}$ generated in situ from $\mathrm{BF}_{3} \cdot \mathrm{OEt}_{2}$ and TMSOTf. One noteworthy aspect of this reduction method is the nearly quantitative mass recovery, which in all cases examined was over $96 \%$, and in the crude ${ }^{1} \mathrm{H}$ NMR spectra of these reactions no unassignable extraneous peaks were observed. While these preliminary results are encouraging, the highly reactive nature of the $\mathrm{BF}_{2} \mathrm{OTf} \cdot \mathrm{OEt}_{2}$ Lewis acid may limit this technique to relatively simple aliphatic esters. Other uses for $\mathrm{BF}_{2} \mathrm{OTf} \cdot \mathrm{OEt}_{2}$ are under investigation, and it is hoped that further optimization of this reduction reaction will lead to a practical method in organic chemistry for ether synthesis.

The analytical data for most of the reported compounds has been reported elsewhere. ${ }^{16}$ TMSOMs and TMSOTf were made according to published procedures. ${ }^{17}$ Dry solvents were obtained from a solvent dispensing system. ${ }^{1} \mathrm{H},{ }^{11} \mathrm{~B},{ }^{13} \mathrm{C}$, and ${ }^{19} \mathrm{~F}$ NMR spectra were obtained on a Varian Inova $400 \mathrm{MHz}$ spectrometer. Chemical shifts are reported in parts per million ( $\mathrm{ppm}$ ) downfield from tetramethylsilane and are, in all cases, referenced to the residual proton resonance peak $\delta 7.25$ for $\mathrm{CDCl}_{3}$. Column chromatography was preformed with Sorbent Technologies 32-63 $\mu \mathrm{m}$ silica gel.

\section{General procedure for reduction of esters:}

A solution of $\mathrm{BF}_{3} \cdot \mathrm{OEt}_{2}(1.8 \mathrm{mmol}, 1.8 \mathrm{eq})$ and TMSOTf $(1.2$ mmol, $1.2 \mathrm{eq})$ were combined with dry toluene $(3 \mathrm{~mL})$ and held under reduced pressure $(40 \mathrm{mmHg}$, rt) for 2 hours. After the vacuum was released and the vessel was back filled with argon, ester $(1 \mathrm{mmol}, 1 \mathrm{eq})$, and $\mathrm{Et}_{3} \mathrm{SiH}$ (5.0 mmol, $\left.5 \mathrm{eq}\right)$ were added sequentially. The reaction mixture was monitored by TLC and upon completion (2-5 days, depending upon steric bulk) was poured into $20 \mathrm{~mL}$ methanol and $20 \mathrm{~mL}$ of water, and diluted with $20 \mathrm{~mL}$ $\mathrm{CH}_{2} \mathrm{Cl}_{2}$. The organic layer was separated, and the aqueous layer was extracted with $\mathrm{CH}_{2} \mathrm{Cl}_{2}(2 \times 5 \mathrm{~mL})$. The combined organic layers were washed with water $(20 \mathrm{~mL})$, brine $(20 \mathrm{~mL})$, dried over $\mathrm{MgSO}_{4}$, filtered through a thin pad of celite, and excess solvent was removed by rotary evaporation. The crude product was purified by flash chromatography (hexanes:EtOAc, 9:1).

$\mathrm{BF}_{2} \mathrm{OMs} \bullet \mathrm{OEt}_{2}$ - Boron difluoride mesylate diethyl etherate
${ }^{1} \mathrm{H}$ NMR previously reported. ${ }^{16 a}$

${ }^{19} \mathrm{~F}$ NMR $\left(375 \mathrm{MHz}, \mathrm{CDCl}_{3}\right) \delta-148.26$ (m, 2F).

${ }^{11} \mathrm{~B}$ NMR (125 MHz, $\left.\mathrm{CDCl}_{3}\right) \delta-0.45$ (broad s).

$\mathrm{BF}_{2} \mathrm{OTf} \bullet \mathrm{OEt}_{2}$ - Boron difluoride triflate diethyl etherate

${ }^{1} \mathrm{H} \mathrm{NMR}\left(400 \mathrm{MHz}, \mathrm{CDCl}_{3}\right) \delta 4.43$ (q, $\left.J=7.0 \mathrm{~Hz}, 4 \mathrm{H}\right), 1.51$ (t, $J$ $=7.0 \mathrm{~Hz}, 6 \mathrm{H})$.

${ }^{19} \mathrm{~F}$ NMR (375 MHz, $\left.\mathrm{CDCl}_{3}\right) \delta-77.24$ (s, 3F), -146.92 (m, 2F).

${ }^{11} \mathrm{~B}$ NMR (125 MHz, $\left.\mathrm{CDCl}_{3}\right) \delta-0.5$ (broad s).

(3-Isobutoxy-propyl)-benzene (Table 2, Entry 2) ${ }^{16 \mathrm{j}}$

Yellow oil; $\mathrm{R}_{f} 0.69$ (20\% EtOAc/hexanes).

${ }^{1} \mathrm{H}$ NMR $\left(400 \mathrm{MHz}, \mathrm{CDCl}_{3}\right) \delta 7.32-7.29(\mathrm{~m}, 2 \mathrm{H}), 7.23-7.19$ $(\mathrm{m}, 3 \mathrm{H}), 3.44(\mathrm{q}, J=6.9 \mathrm{~Hz}, 2 \mathrm{H}), 3.20(\mathrm{~d}, J=6.9 \mathrm{~Hz}, 2 \mathrm{H}), 2.73(\mathrm{t}$, $J=6.9 \mathrm{~Hz}, 2 \mathrm{H}), 1.96-1.87(\mathrm{~m}, 2 \mathrm{H}), 0.96(\mathrm{~s}, 3 \mathrm{H}), 0.94(\mathrm{~s}, 3 \mathrm{H})$.

${ }^{13} \mathrm{C}$ NMR $\left(100 \mathrm{MHz}, \mathrm{CDCl}_{3}\right) \delta 142.1,128.5,128.2,125.7,77.8$, $69.9,32.3,31.3,28.4,19.4$

[3-(2,2-Dimethyl-propoxy)-propyl]-benzene (Table 2, Entry 3) ${ }^{16 \mathrm{~h}}$

Yellow oil; $\mathrm{R}_{f} 0.70$ (20\% EtOAc/hexanes).

${ }^{1} \mathrm{H}$ NMR $\left(400 \mathrm{MHz}, \mathrm{CDCl}_{3}\right) \delta 7.30-7.26(\mathrm{~m}, 2 \mathrm{H}), 7.21-7.16$ $(\mathrm{m}, 3 \mathrm{H}), 3.42(\mathrm{t}, J=6.9 \mathrm{~Hz}, 2 \mathrm{H}), 3.06(\mathrm{~s}, 2 \mathrm{H}), 2.70(\mathrm{t}, J=6.9 \mathrm{~Hz}$, $2 \mathrm{H}), 1.92-1.85(\mathrm{~m}, 2 \mathrm{H}), 0.93(\mathrm{~s}, 9 \mathrm{H})$.

${ }^{13} \mathrm{C}$ NMR $\left(100 \mathrm{MHz}, \mathrm{CDCl}_{3}\right) \delta 142.2,128.5,128.2,125.6,81.3$, $70.4,32.3,32.1,31.3,26.8$.

Bis(3-phenylpropyl) ether (Table 2, Entry 6) ${ }^{16 \mathrm{i}}$

Pale yellow liquid; $\mathrm{R}_{f} 0.43$ (20\% EtOAc/hexanes).

${ }^{1} \mathrm{H}$ NMR (400 MHz, $\left.\mathrm{CDCl}_{3}\right) \delta 7.32-7.27(\mathrm{~m}, 2 \mathrm{H}), 7.22-7.15$ $(\mathrm{m}, 3 \mathrm{H}), 4.09(\mathrm{t}, J=6.5 \mathrm{~Hz}, 2 \mathrm{H}), 2.96(\mathrm{t}, J=7.8 \mathrm{~Hz}, 2 \mathrm{H}), 2.64(\mathrm{t}$, $J=6.5 \mathrm{~Hz}, 4 \mathrm{H}), 1.97-1.90(\mathrm{~m}, 2 \mathrm{H})$.

${ }^{13} \mathrm{C}$ NMR $\left(100 \mathrm{MHz}, \mathrm{CDCl}_{3}\right) \delta 142.0,128.4,128.3,152.7,69.9$, $32.4,31.3$.

\section{Acknowledgment}

We thank NSERC and The University of Western Ontario for financial support of this work.

\section{References}

(1) Dilman, A. D.; Ioffe, S. L. Chem. Rev. 2003, 103, 733-772. (b) Zhao, H., Gorman J. S.; Pagenkopf B. L. Org. Lett. 2006, 8, 4379-4382 . (c) Mahrwald, R. Chem. Rev. 1999, 99, 1095-1120. (d) Corma, A.; Garcia, H. Chem. Rev. 2002, 102, 3837-3892. (e) Zhao, H.; Engers, D. W.; Morales, C. L.; Pagenkopf, B. L. Tetrahedron 2007, 63, 8774-8780.

(2) Snider, B.B. In Comprehensive Organic Chemistry; Trost, B.M.; Flemming, I., Eds.; Pergamon Press: Oxford, 1991; Vol. 2, Chap. 2.1, p. 527-561.

(3) Konig, K.; Neumann, W.P. Tetrahedron Lett. 1967, 6, 495498.

(4) (a) Kagan, H. B.; Riant, O. Chem. Rev. 1992, 92, 10071019. (b) Pindur, U.; Lutz, G.; Otto, C. Chem. Rev. 1993, 93, 741-761. 
(5) Carreira, E. M. In Modern Carbonyl Chemistry; Otera, J., Ed.; Wiley: Weinheim, 2000; Chap. 8, p. 227.

(6) During the preparation of this manuscript, Sakai reported the one-pot synthesis of unsymmetrical ethers via deoxygenation of esters using an $\mathrm{InBr}_{3} / \mathrm{Et}_{3} \mathrm{SiH}$ catalytic system: Sakai, N.; Moriya, T.; Konakahara, T.; J. Org. Chem. 2007, 72, 5920-5922.

(7) It is important to note that after its original discovery (ref 7a) Gray used this reductive cleavage method to quantitatively identify the positions of substitution of acetyl, butyr$\mathrm{yl}$ and propionyl groups in cellulose derivatives (ref 7b-7c). (a) Sherman, J. S.; Gray, G. R. Carbohydr. Res. 1992, 231, 221-235. (b) Lee, C. K.; Gray, G. R.; Carbohydr. Res., 1995, 269, 167-174. (c) Yu, N.; Gray, G. R.; Carbohydr. Res., 1998, 312, 225-231. (d) Yu, N.; Gray, G. R.; Carbohydr. Res., 1998, 313, 29-36.

(8) (a) Fuhrmann, E.; Talbiersky, J. Org. Process Res. Dev. 2005, 9, 206 -211. (b) Paul, S.; Gupta, M. Tetrahedron Lett. 2004, 45, 8825-8829.

(9) Jun J.-G.; Gray, G. R. Carbohydr. Res. 1987, 163, 247-261.

(10) Hoye, T. R.; Eklove, B. M.; Ryba, T. D.; Voloshin, M; Yao, L. J. Org. Lett. 2004, 6, 953-956.

(11) Myers, E. L.; Butts, C. P, Aggarwal, V. K. Chem. Commun. 2006, 42, 4434-4436.

(12) Myers, E. L.; de Vries, J. G.; Aggarwal, V. K. Angew. Chem., Int. Ed. 2007, 46, 1893.

(13) NMR analysis of the mixture showed the regeneration of $\mathrm{BF}_{3} \cdot \mathrm{OEt}_{2}$ as well as peaks tentatively assigned to $\mathrm{BF}(\mathrm{OTf})_{2} \cdot \mathrm{OEt}_{2}$, and $\mathrm{B}(\mathrm{OTf})_{3} \cdot \mathrm{OEt}_{2}$ :

${ }^{1} \mathrm{H}$ NMR showed two new etherate peaks downfield of $\mathrm{BF}_{2} \mathrm{OTf} \bullet \mathrm{OEt}_{2}[4.74(\mathrm{q}, J=7.0 \mathrm{~Hz}, 4 \mathrm{H}), 1.65(\mathrm{t}, J=7.0 \mathrm{~Hz}$, $6 \mathrm{H})$ and $4.61(\mathrm{q}, J=6.9 \mathrm{~Hz}, 4 \mathrm{H}), 1.60(\mathrm{t}, J=6.9 \mathrm{~Hz}$, $6 \mathrm{H})]$.

${ }^{11} \mathrm{~B}$ NMR showed two new singlets upfield of the $\mathrm{BF}_{2} \mathrm{OTf} \bullet \mathrm{OEt}_{2}(-1.54,-2.28)$.

${ }^{19} \mathrm{~F}$ NMR showed two new singlets in the triflate region $(-75.47,-77.40)$.

(14) The ${ }^{29} \mathrm{~F}$ NMR of a reaction run under Conditions A (see footnote Table 2) showed the presence of a peak at -178 ppm suggesting the formation of triethylsilyl fluoride, which is likely responsible for the formation of the triethylsilyl ether product. The signal at $-178 \mathrm{ppm}$ was absent under Conditions B.

(15) Kenneth, J. B.; Scott, C. B.; Buchwald, S.L.; J. Org. Chem. 1994, 59, 4323-4326.

(16) (a) Jun J.-G.; Ha T. H.; Kim D.-W. Tetrahedron Lett. 1994, 35, 1235-1238. (b) Acetic acid 3-phenyl-propyl ester: Kobayashi, K.; Watahiki, T.; Oriyama, T. Synthesis 2003, 4, 484-486. (c) (3-Ethoxy-propyl)-benzene: Matsubara, K.; Iura, T.; Maki, T.; Nagashima, H. J. Org. Chem. 2002, 67, 4985-4988. (d) Triethyl-(3-phenyl-propoxy)-silane: Hayashi, M.; Matsuura, Y.; Watanabe, Y. Tetrahedron Lett. 2004, 45, 1409-1412. (e) Isobutyric acid 3-phenyl-propyl ester, 2,2-dimethyl-propionic acid 3-phenyl-propyl ester: Werner, T.; Barrett, A. J. Org. Chem. 2006, 71, 43024304. (f) Formic acid 3-phenyl-propyl ester: Luca, L. D.; Giacomelli, G.; Porcheddu, A. J. Org. Chem. 2002, 67, 5152-5155. (g) (3-Methoxy-propyl)-benzene: Bodwell, G. J.; Li, J.; Miller, D. O. Tetrahedron 1999, 55, 12939-12956. (h) 3-Phenyl-propionic acid methyl ester: Crosignani, S.; White, P. D.; Linclau, B. J. Org. Chem. 2004, 69, $5897-$ 5905. (i) 3-Phenyl-propionic acid 3-phenyl-propyl ester: Kopecky, D. J.; Rychnovsky, S. D. J. Org. Chem. 2000, 65, 191-198. (j) Mizuno, K.; Ogawa, J.; Otsugi, Y. Chem. Lett. 1981, 6, 741-744. (h) Kato, J.-I.; Iwasawa, N.; Mukaiyama, T. Chem. Lett. 1985, 6, 743-746. (i) Harnet, A. M.; He, H. S.; Toy, P. H.; Flynn, D. L.; Hanson, P. R. J. Am. Chem. Soc. 2005, 127, 52-53.
(17) (a) Schmidbaur, H.; Sechser, L.; Schmidt, M. J. Organomet. Chem. 1968, 15, 77-87. (b) Krolikiewicz, K.; Bennua, B. Chem. Ber. 1981, 114, 1234-1255. 
Graphical Abstract:

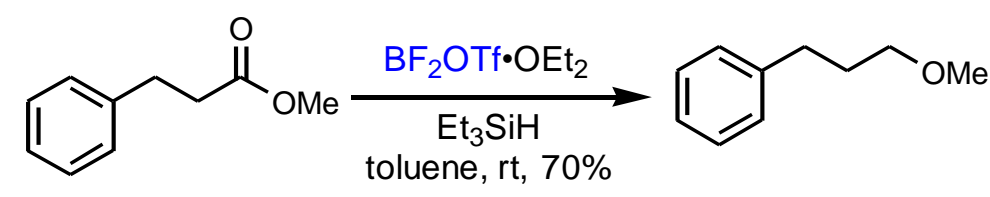

